\section{A Comparison of Techniques for Determining Nitrogen Release from Polymer-coated Urea in the Field}

\author{
Melissa L. Wilson, Carl J. Rosen ${ }^{1}$, and John F. Moncrief \\ Department of Soil, Water, and Climate, University of Minnesota, 1991 \\ Upper Buford Circle, St. Paul, MN 55108
}

Additional index words. controlled-release fertilizer, nitrogen release characteristics, mesh bag, potato, weight method

\begin{abstract}
Although laboratory analyses of nitrogen (N) release from polymer-coated urea (PCU) are available for most brands of PCU, data are lacking for release patterns under field conditions. Release rate studies for $P C U$ are often time-consuming and expensive as a result of the need for multiple chemical analyses. We compared the $\mathrm{N}$ release using a weight loss method with a direct chemical analysis method for two types of PCU (Agrium PCU, Agrium U.S. Inc.; Kingenta PCU, Shandong Kingenta Ecological Engineering Co., Ltd.). The PCU prills were placed in a mesh bag and N loss from the prills over time was determined indirectly by loss in weight. The $\mathrm{N}$ content of the prills was determined by the combustion method to verify the weight method technique. A second study was conducted to determine if the type of mesh bag material affects the percentage of $\mathrm{N}$ released. For this study, mesh bags were constructed from two different materials with two different hole sizes and total amount of open area. Overall, regression analysis suggested that the percentage of $\mathrm{N}$ released as estimated by the weight method and combustion method was not significantly different over the growing season for two types of PCU. The mesh bags made of the material with smaller holes and less open area resulted in significantly less $\mathbf{N}$ release than the material with more open area and larger holes. Overall, these results suggest that the weight method can be reliably used as a substitute for chemical analysis to determine $N$ release characteristics of $P C U$, but mesh bag materials must be taken into consideration to reduce errors. The best technique to determine $\mathbf{N}$ release may be one that does not include a mesh bag; however, until that method is developed, using a larger hole size is recommended.
\end{abstract}

Controlled-release fertilizers are being used more frequently for crop production in an effort to improve plant nitrogen $(\mathrm{N})$ use efficiency and reduce nitrate leaching. Polymer-coated urea (PCU) is a controlled-release fertilizer that releases $\mathrm{N}$ over time. The success in improving $\mathrm{N}$ use efficiency depends on matching $\mathrm{N}$ release with $\mathrm{N}$ demand by the crop (Shaviv, 2001). Through manipulation of the coating, manufacturers have control over $\mathrm{N}$ release patterns in PCU that can be matched to the uptake of specific crops (Trenkel, 1997), and currently there are a variety of brands available with differing $\mathrm{N}$ release characteristics.

\footnotetext{
Received for publication 12 Sept. 2008. Accepted for publication 3 Dec. 2008.

Support for this project was provided in 2005 by the Environment and Natural Resources Trust Fund as recommended by the Legislative Commission on Minnesota Resources. Partial funding was also provided by Agrium U.S., Inc. and Shandong Kingenta Ecological Engineering Co., Ltd., China. Mention of a trademark, proprietary product, or vendor does not constitute a guarantee or warranty of the product by the University of Minnesota and does not imply its approval to the exclusion of other products or vendors that also may be suitable.

${ }^{1}$ To whom reprint requests should be addressed; e-mail crosen@umn.edu.
}

Although there are many types of PCU available to crop producers, there is a lack of knowledge about $\mathrm{N}$ release patterns under field conditions. Conventionally, dissolution of urea in PCU is determined from a static test in which PCU is dissolved in water and the refractive index of the solution is determined as a function of time (Salman et al., 1989). These laboratory measurements are often the only information available to consumers about PCU N release characteristics, although there is generally a lack of correlation between these and field measurements (Trenkel, 1997).

Several studies have reported patterns of $\mathrm{N}$ release using varying techniques, but no standardized test exists. Simonne and Hutchinson (2005) used pot-in-pot trials in the field to measure the number of days needed to recover specific amounts of applied N. In that study, leachate samples were collected from the lower pot and analyzed for recovered $\mathrm{NO}_{3}-\mathrm{N}$ and $\mathrm{NH}_{4}-\mathrm{N}$. The most common technique, however, is to enclose a known amount of PCU into a bag of porous material and bury it in the field. These mesh bags are removed over time to estimate $\mathrm{N}$ loss. However, the type of material used for mesh bags and the determination of $\mathrm{N}$ loss varies by study. Pack (2004) used cheesecloth and then ground the PCU prills to dissolve the remaining urea in a known amount of water. The solution was then analyzed by a total Kjeldahl nitrogen method (TKN). Gandeza et al. (1991) and Zvomuya et al. (2003) used plastic mesh and directly analyzed the prills by TKN. Savant et al. (1982) and Salman et al. (1989) used nylon screen and determined the loss of urea by the loss of weight from the prills. Although the two weight loss studies were conducted in soil, they were not conducted under field conditions.

With the exception of the latter two studies, the percentage of $\mathrm{N}$ released from PCU was determined with chemical analysis, which can be expensive and time-consuming. The weight method presented in Savant et al. (1982) may reduce the costs of a PCU release rate study, but it has not been validated with chemical analysis.

The reliability of the method also depends on the material used for the mesh bags that enclose the fertilizer. For instance, a proper material should allow the PCU to be exposed to soil and the same moisture conditions that affect the intended crop. A material with hole openings that are too small may reduce exposure, whereas one with large openings may allow fertilizer to fall out of the container.

The objectives of this study were to 1) compare the weight method with direct chemical analysis for determining $\mathrm{N}$ release characteristics of PCU; and 2) determine the effect of mesh bag material type on $\mathrm{N}$ release from PCU.

\section{Materials and Methods}

Field experiments were conducted over the 2007 growing season as part of a larger study to evaluate PCU rate and timing at the Sand Plain Research Farm in Becker, MN. The soil at this site is a Hubbard loamy sand (sandy, mixed, frigid Typic Hapludoll). The experimental crop was 'Russet Burbank' potato (Solanum tuberosum L.) planted on 26 Apr. and hilled at emergence on 15 May. The crop was irrigated according to the checkbook method (Wright, 2002). Details of management and cultural practices can be found in Wilson (2008).

Two experiments were conducted: 1) to test methods of determining the percent of $\mathrm{N}$ released ( $\% \mathrm{NR}$ ) from PCU; and 2) to test the effect of mesh bag materials on $\mathrm{N}$ release. Two types of PCU were tested in the first experiment. The first was a $90-\mathrm{d}$ release PCU (44-0-0) marketed as Environmentally Smart Nitrogen from Agrium U.S. Inc. (Denver, CO) (Agrium PCU). The second was a 90- to 120-d release PCU (42-0-0) produced by Shandong Kingenta Ecological Engineering Co., Ltd., (Linyi, Shandong, China) (Kingenta PCU). The release periods listed are those reported by the manufacturer.

The second experiment tested two different types of material for construction of mesh bags. Only Agrium PCU was used in the second experiment. The first material was polypropylene mesh (Industrial Netting, Minneapolis, $\mathrm{MN}$ ) with $1.2-\mathrm{mm}^{2}$ hole openings and a $43 \%$ open area (this was also the material used in the first experiment). The second was weedblock landscape material 
(Easy Gardener Weedblock Fabric, Waco, TX) from a local hardware store made of polyethylene with a hole size of $\approx 0.07 \mathrm{~mm}^{2}$ and an open area of $24 \%$. For both experiments, mesh bags were $\approx 10 \mathrm{~cm} \times 10 \mathrm{~cm}$ and heat-sealed with an impulse sealer (ULINE, Chicago, IL) along three edges. Finally, $3 \pm$ $0.0002 \mathrm{~g}$ of $\mathrm{PCU}(\approx 174$ and 113 prills for Agrium and Kingenta PCU, respectively) were placed in the bags and then the open side was heat-sealed.

The experimental design for both experiments was randomized complete blocks. The first experiment had three replicates, whereas the second experiment had two replicates. Each replicate consisted of 10 bags that were buried in the potato hill and subject to the same temperature and moisture conditions as fertilizer placed in the hill. In Expt. 1, Kingenta PCU was buried in the field $6 \mathrm{~d}$ before planting on 20 Apr. to a depth of 5 to $10 \mathrm{~cm}$, because potato hills were not formed until the day of planting. This treatment was intended to simulate a preplant application of PCU. Agrium PCU was buried at planting on 26 Apr. to the depth of the fertilizer band $(\approx 25$ $\mathrm{cm})$ to simulate a banded PCU application. Kingenta PCU mesh bags were then transferred to the plots and buried at 5 to $10 \mathrm{~cm}$ in the potato hill. Although the dates and placement of mesh bags were different for each material, these differences should not affect achieving the objectives of this study. In Expt. 2, mesh bags of each type were buried on 15 May $\approx 5 \mathrm{~cm}$ below the top of the hill to simulate N release from Agrium PCU applied at emergence. For both experiments, one mesh bag was retrieved from each replicate at $\approx 2$-week intervals until the end of the growing season. Fertilizer prills were airdried in the mesh bags for a minimum of $14 \mathrm{~d}$ before processing. The prills were then removed manually from each mesh bag, separated from soil, and then weighed.

Two different methods were used to calculate $\% \mathrm{NR}$ over the course of the growing season in the first experiment. The first is a modified technique (Savant et al., 1982) using the change in prill weights over time. First, the weight of the polymer coating in $3 \mathrm{~g}$ of PCU was determined using the following equation:

$$
\mathrm{F}_{\mathrm{C}}=\mathrm{F}_{\mathrm{i}}-\left[\frac{\mathrm{F}_{\mathrm{i}} *\left(\% \mathrm{~N}_{\mathrm{PCU}}\right)}{\% \mathrm{~N}_{\text {urea }}}\right]
$$

where $F_{C}$ is the weight of the polymer coating in grams, $F_{i}$ is the initial amount of PCU in the mesh bags, $\% \mathrm{~N}_{\mathrm{PCU}}$ is the percent of $\mathrm{N}$ in the PCU product, and $\% \mathrm{~N}_{\text {urea }}$ is the percent of $\mathrm{N}$ in uncoated urea. Based on the manufacturer's $\mathrm{N}$ analysis, the weight of polymer coating in $3 \mathrm{~g}$ of fertilizer was calculated to be 0.13 and $0.26 \mathrm{~g}$ for Agrium PCU and Kingenta PCU, respectively. The \%NR for each sampling date was then determined by the following equation:

$$
\% \mathrm{NR}_{\mathrm{W}}=\left[1-\left(\frac{\mathrm{F}_{\mathrm{s}}-\mathrm{F}_{\mathrm{c}}}{\mathrm{F}_{\mathrm{i}}-\mathrm{F}_{\mathrm{c}}}\right)\right] * 100
$$

where $\% \mathrm{NR}_{\mathrm{W}}$ is the percent of $\mathrm{N}$ release as determined by the weight method, $\mathrm{F}_{\mathrm{s}}$ is the weight of the PCU on the sampling date, $F_{c}$ is the weight of the polymer coating, and $F_{i}$ is the initial amount of PCU in the mesh bag.

For the second method, \%NR was determined by chemical analysis. Fertilizer prills from each sampling date were air-dried, crushed in a mortar and pestle, and then $\mathrm{N}$ was determined using a combustion analyzer (LECO FP-528 Total Nitrogen Analyzer; LECO, St. Joseph, MI) following the general methods for plant material in Horneck and Miller (1998). The N found by combustion was multiplied by the weight of the prill sample to determine $\mathrm{N}$ content remaining in the prills. The $\% \mathrm{NR}$ for each sampling date was then determined by the following equation:

$$
\% \mathrm{NR}_{\mathrm{C}}=\left[1-\left(\frac{\mathrm{N}_{\mathrm{s}}}{\mathrm{N}_{\mathrm{i}}}\right)\right] * 100
$$

where $\% \mathrm{NR}_{\mathrm{C}}$ is the percent of $\mathrm{N}$ release as determined by the combustion method, $\mathrm{N}_{\mathrm{s}}$ is the $\mathrm{N}$ content in grams of the $\mathrm{PCU}$ on the sampling date, and $\mathrm{N}_{\mathrm{i}}$ is the initial $\mathrm{N}$ content in $3 \mathrm{~g}$ of PCU as determined by combustion. The actual $\mathrm{N}$ concentration in the prills on Day 0 before mesh bag burial was $44.5 \% \pm$ $0.2 \%$ for Agrium PCU and $42.8 \% \pm 0.6 \%$ for Kingenta PCU based on combustion analysis. Only the weight method was used to determine $\% \mathrm{NR}$ in the second experiment.

Pearson correlation coefficients in PROC CORR were used to determine the association between the weight and combustion methods of calculating \%NR and PROC REG was used to fit a linear regression line to the data (SAS Institute Inc., 2004). To further compare the two methods in each experiment, \%NR was also plotted as a function of days after planting (DAP). On the day that mesh bags were buried, $\mathrm{N}$ release was assumed to be zero. Regression models were fit for each treatment and analyzed in PROC MIXED (SAS Institute Inc., 2004). This method compares intercept and slope coefficients of lines to determine if they are statistically different. Coefficients were considered significantly different at probability levels less than $5 \%$.

\section{Results and Discussion}

Expt. 1: Methods to determine percent nitrogen release from polymer-coated urea. The weight and combustion methods of determining the percent of $\mathrm{N}$ release $(\% \mathrm{NR})$ were highly correlated $(P<0.0001)$ for both Agrium and Kingenta PCU with correlation coefficients greater than 0.999 (Figs. 1 and 2, respectively). For both PCUs, the slope of the regression line was also near $1 \pm 0.05$. This indicates that the $\% \mathrm{NR}$ on each sampling date was at an approximate 1:1 ratio, which also means that predicted \%NR by each method was similar at every sampling date. A slope below or above 1 would imply that one method produced higher or lower values than the other method.

To further explore if $\mathrm{N}$ release found by each method was similar, equations were fit to each data set as a function of DAP. For

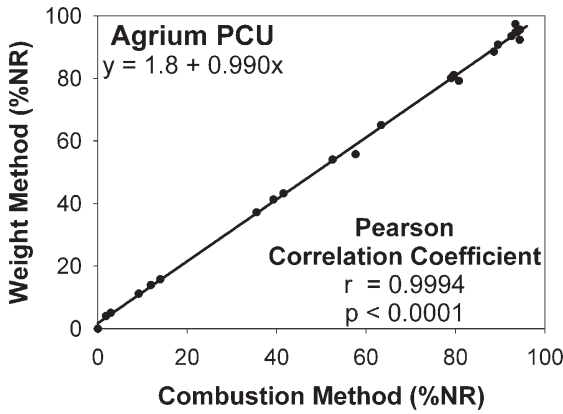

Fig. 1. The correlation between two different methods for determining percent $\mathrm{N}$ release $(\% \mathrm{NR})$ for Agrium polymer-coated urea (PCU) incubated at the fertilizer band depth of the potato hill. Each point represents one paired observation.

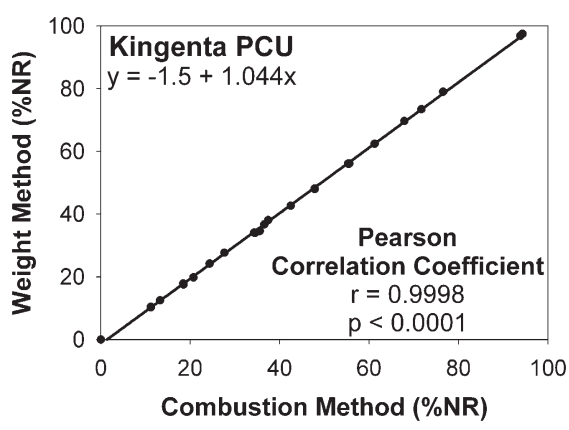

Fig. 2. The correlation between two different methods for determining percent $\mathrm{N}$ release $(\% \mathrm{NR})$ for Kingenta polymer-coated urea (PCU) incubated at the fertilizer band depth of the potato hill. Each point represents one paired observation.

Agrium PCU, a quadratic equation modeled the response of $\mathrm{N}$ release rate with time (Fig. 3). Gandeza et al. (1991) and Zvomuya et al. (2003) also reported a quadratic release model for $\% \mathrm{NR}$ of a different PCU. For Agrium PCU, the slope and intercept coefficients from each method were not significantly different $(P>0.10)$. Percent $\mathrm{N}$ release peaked at $\approx 97 \%$ between 135 and 140 DAP. Nitrogen release from PCU most likely reached a plateau after this point because

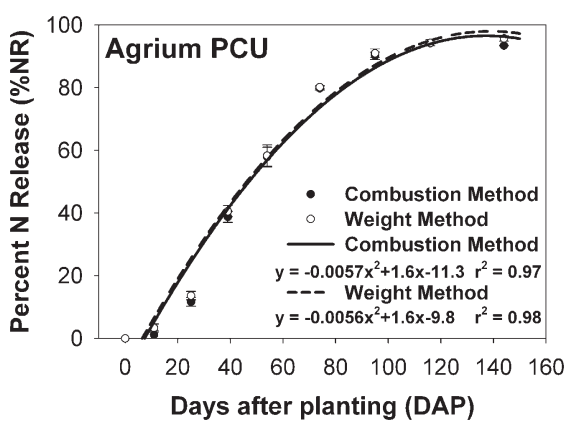

Fig. 3. Percent of nitrogen release $(\% N R)$ as a quadratic function of days after planting (DAP) for Agrium polymer-coated urea (PCU) incubated at the fertilizer band depth of the potato hill. Each point represents the mean and $1 \mathrm{SE}$. 


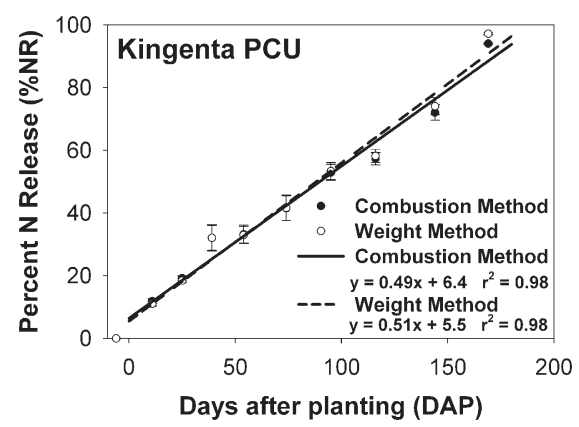

Fig. 4. Percent of nitrogen release $(\% N R)$ as a linear function of days after planting (DAP) for Kingenta polymer-coated urea (PCU) incubated at the fertilizer band depth of the potato hill. Each point represents the mean and $1 \mathrm{SE}$.

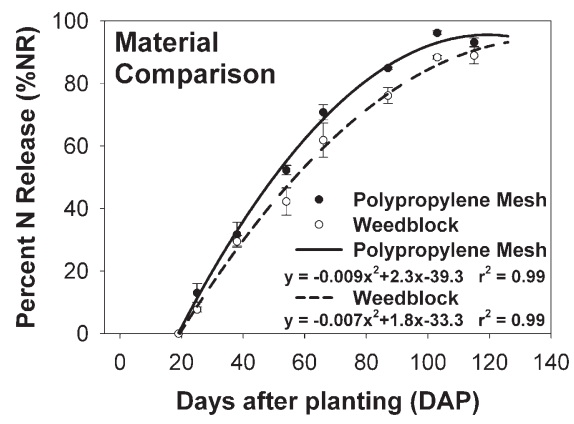

Fig. 5. Percent of nitrogen release $(\% N R)$ as a quadratic function of days after planting (DAP) for Agrium polymer-coated urea (PCU) as influenced by mesh bag material. Each point represents the mean and $1 \mathrm{sE}$.

the fertilizer cannot release more than $100 \%$. For Kingenta PCU, \%NR was found to be a linear function of DAP (Fig. 4). Again, the slope and intercept were not significantly different between methods. The linear response suggests that the peak \%NR had not been reached by the last sampling date. Both methods resulted in similar \%NR over time for the two different types of PCU, although $\mathrm{N}$ release patterns varied between $\mathrm{N}$ sources. This provides strong evidence that the weight method can be considered a good predictor of $\mathrm{N}$ release for the products evaluated. Depending on the coating, there is potential for some PCU products to retain water when air-dried, which would affect the weight and underestimate $\mathrm{N}$ release using the weight method. However, we did not encounter this as being a problem in the present study.
Expt. 2: Mesh bag material comparison. The $\mathrm{N}$ release of Agrium PCU from two different types of mesh as a function of DAP was found to fit a quadratic model (Fig. 5). The linear coefficients of each line were significantly different for each material $(P<0.05)$. The quadratic coefficients were not different at $P=0.05$, although a trend was noted at $P=$ 0.07 . The constant coefficients, or intercept, were not significantly different for each material $(P>0.10)$. Initially, $\% \mathrm{NR}$ with both types of mesh bags appears to be similar, but after 40 DAP, \%NR with weedblock was lower than with polypropylene mesh. After removing mesh bags from the potato hill, prills in the weedblock bags were typically cleaner than prills in polypropylene. This suggests that the polypropylene mesh allowed prills to come in closer contact to the soil compared with weedblock bags and may explain the difference in $\%$ NR. Because PCU prills are in complete contact with the soil when applied to crops, polypropylene mesh may provide a better estimate for actual $\mathrm{N}$ release in the soil than weedblock bags. Pack (2004) used cheesecloth as a material for mesh bags, which would also prohibit contact with the soil, but the methods in that study required $200 \mathrm{~g}$ of soil to be placed in the bags with the fertilizer. Although this may solve the problem of prill contact with soil, removing the prills from the soil may be more time-consuming and it is unclear if water movement into the bag would be affected. When developing a standard procedure for $\mathrm{N}$ release from $\mathrm{PCU}$, further research should consider the effect of mesh bag materials or if inclusion of soil in the bag further enhances $\mathrm{N}$ release. The best technique for determining $\mathrm{N}$ release characteristics of PCU in the soil may be one that does not include a mesh bag. However, until that technique is further developed, using the largest possible hole size is recommended.

\section{Conclusions}

The N release characteristics of two PCUs were determined with the weight method and by combustion analysis. Both methods resulted in the same percent $\mathrm{N}$ release over time for both $\mathrm{N}$ sources, which suggests that the mesh bag weight method can be reliably used for determining PCU $\mathrm{N}$ release characteristics. The effect of mesh bag material on $\mathrm{N}$ release of PCU was also examined. Weedblock material, which has smaller hole openings and less total open area, resulted in significantly lower $\mathrm{N}$ release over the grow- ing season than a polypropylene mesh with larger hole openings and more open area. The difference between materials was most likely the result of hole size, which restricted the interaction between soil and fertilizer. When conducting mesh bag experiments to determine $\mathrm{N}$ release characteristics of a PCU, it is important to choose a material that will not limit exposure to water and soil.

\section{Literature Cited}

Gandeza, A.T., S. Shoji, and I. Yamada. 1991. Simulation of crop response to polyolefincoated urea: I. Field dissolution. Soil Sci. Soc. Amer. J. 55:1462-1467.

Horneck, D.A. and R.O. Miller. 1998. Determination of total nitrogen in plant tissue. In: Kalra, Y.P. (ed.). Handbook of reference methods for plant analysis. CRC Press, Boston, MA.

Pack, J.E. 2004. Controlled-release nitrogen fertilizer release characterization and its effects on potato (Solanum tuberosum) production and soil nitrogen movement in Northeast Florida. MSc thesis, University of Florida, Gainesville, FL.

Salman, O.A., G. Hovakeemian, and N. Khraishi. 1989. Polyethylene-coated urea. 2. Urea release as affected by coating material, soil type, and temperature. Ind. Eng. Chem. Res. 28:633638.

Savant, N.K., J.R. Clemmons, and A.F. James. 1982. A technique for predicting urea release from coated urea in wetland soil. Commun. in Soil Sci. and Plant Anal. 13:793-802.

SAS Institute. 2004. SAS/STAT ${ }^{\circledR} 9.1$ user's guide. SAS Inst., Cary, NC.

Shaviv, A. 2001. Advances in controlled release fertilizers. In: Sparks, D.L. (ed.). Advances in agronomy. Vol. 71. Academic Press, San Diego, CA.

Simonne, E.H. and C.M. Hutchinson. 2005. Controlled release fertilizers for vegetable production in the era of best management practices: Teaching new tricks to an old dog. HortTechnology 15:36-46.

Trenkel, M.E. 1997. Improving fertilizer use efficiency: Controlled-release and stabilized fertilizers in agriculture. International Fertilizer Industry Association, Paris, France.

Wilson, M.L. 2008. Crop productivity and nitrate leaching in coarse-textured soils as affected by the use of polymer-coated urea and deep tillage. Univ. of Minnesota, Saint Paul, MN. M.S. thesis.

Wright, J. 2002. Irrigation scheduling: Checkbook method. FO-01322. Univ. of Minnesota Ext. Serv., Saint Paul, MN.

Zvomuya, F., C.J. Rosen, M.P. Russelle, and S.C. Gupta. 2003. Nitrate leaching and nitrogen recovery following application of polyolefincoated urea to potato. J. Environ. Qual. 32:480489. 